\title{
Phylogenetic analysis of genus Marinilabilia and related bacteria based on the amino acid sequences of GyrB and emended description of Marinilabilia salmonicolor with Marinilabilia agarovorans as its subjective synonym
}

\author{
Makoto Suzuki, ${ }^{1} \dagger$ Yasuyoshi Nakagawa, ${ }^{2}$ Shigeaki Harayama ${ }^{1}$ \\ and Satoshi Yamamoto'
}

\author{
Author for correspondence: Makoto Suzuki. Tel: +8142725 2555. Fax: +81427268330 . \\ e-mail: makoto.suzuki@kyowa.co.jp
}

\footnotetext{
1 Marine Biotechnology Institute, Kamaishi Laboratories, Kamaishi, Iwate 026-0001, Japan

2 Institute for Fermentation, Osaka, 2-17-85 JyusoHoncho, Yodogawa-ku, Osaka 532-0024, Japan
}

\begin{abstract}
The detailed phylogenetic relationships for genus Marinilabilia and related taxa were analysed by using DNA gyrase B subunit gene (gyrB) sequences. Anaerobic bacteria in the Cytophaga-Flavobacterium-Bacteroides phylum, namely genera Marinilabilia, Bacteroides, Rikenella, Prevotella and Porphyromonas and Cytophaga fermentans, were clustered in the same branch and the facultative anaerobes Marinilabilia and Cytophaga fermentans formed a subcluster in the branch of the anaerobic bacteria. Phylogenetic analysis using 165 rDNA sequences gave a similar result but with a lower bootstrap value for each cluster. The gyrB sequences of Marinilabilia salmonicolor and Marinilabilia agarovorans were the same, and the relatedness of their chromosomal DNA, as determined by DNA-DNA hybridization, was greater than $70 \%$. These genetic aspects led to the conclusion that $M$. salmonicolor IFO $15948^{\top}$ and $M$. agarovorans IFO $14957^{\top}$ belong to a single species. Since $M$. salmonicolor was described first, as Cytophaga salmonicolor, $M$. salmonicolor is a senior subjective synonym of $\boldsymbol{M}$. agarovorans. Therefore, the name $\boldsymbol{M}$. salmonicolor should be retained and strain IFO $14957^{\top}$ should be reclassified as M. salmonicolor. However, the agar-degrading ability of strain IFO $14957^{\top}$ is a prominent biochemical characteristic. It is therefore proposed that strain IFO $14957^{\top}$ should be renamed $M$. salmonicolor biovar agarovorans.
\end{abstract}

Keywords: Marinilabilia, Cytophaga-Flavobacterium-Bacteroides complex, gyrB, phylogeny

\section{INTRODUCTION}

Winogradsky (1929) established the genus Cytophaga for aerobic, cellulolytic soil bacteria showing gliding motility. Subsequently, this genus has included mor-

\footnotetext{
† Present address: Tokyo Research Laboratories, Kyowa Hakko Kogyo Co. Ltd, 3-6-6 Asahi-machi, Machida-shi, Tokyo 194-8533, Japan.

Abbreviation: CFB, Cytophaga-Flavobacterium-Bacteroides.

The DDBJ accession numbers for the gyr $B$ sequences reported in this paper are AB15029 (IFO 14291'), AB15026 (ATCC 43767'), AB15024 (IAM 14198'), $A B 15025$ (IFO 14944'), AB15038 (IFO 16043'), AB15037 (IAM 12607'), $A B 15028$ (IFO 14943'), AB15032 (IFO 15948'), AB15033 (IFO 14957'), AB15036 (IAM 14210'), AB15035 (IFO 12017'), AB15027 (ATCC 43766'), $A B 15030$ (JCM 6326'), AB15031 (IFO 15936') and AB15034 (JCM 2053').
}

phologically similar bacteria exhibiting gliding motility. Many of them were isolated from marine environments and degraded cellulose, agar or chitin (Bachmann, 1955; Stanier, 1940, 1941, 1942; Veldkamp, 1961). Some of these species were shown to grow not only aerobically but also anaerobically (Bachmann, 1955; Veldkamp, 1961). More recent taxonomic investigations have shown an overlap between the genera Cytophaga and Flavobacterium (Callies \& Mannheim, 1978; Christensen, 1977; Hayes, 1977; Oyaizu \& Komagata, 1981; Shewan \& McMeekin, 1983). The bacteria in these groups were then called the Cytophaga-Flavobacterium complex, and included the genera Flexibacter, Microscilla, Sporocytophaga and Chitinophaga, which resemble 
Cytophaga or Flavobacterium in their morphological and phenotypic characteristics (Christensen, 1977; Shewan \& McMeekin, 1983).

Systematic bacterial studies have advanced by adopting molecular approaches such as DNA-rRNA hybridization (Palleroni et al., 1973), 16S rRNA cataloguing (Woese et al., 1985) and 16S rRNA sequencing (Woese, 1987). Such investigations have revealed an unexpected relationship between the Cytophaga-Flavobacterium group and the genus Bacteroides (Gherna \& Woese, 1992; Paster et al., 1985; Weisburg et al., 1985). The CytophagaFlavobacterium-Bacteroides (CFB) group currently represents one of eleven phyla of bacteria (Olsen \& Woese, 1993; Woese, 1987). Phylogenetic studies that have used 16S rRNA sequences, chemotaxonomic studies and other phenotype analyses have resulted in several taxa of the CFB complex being rearranged (Bernardet et al., 1996; Nakagawa \& Yamasato, 1996; Nakagawa et al., 1997; Segers et al., 1993; Shah \& Collins, 1988; Steyn et al., 1998).

The genus Marinilabilia was created for the marine, facultatively anaerobic Cytophaga species, Cytophaga salmonicolor and Cytophaga agarovorans, by Nakagawa \& Yamasato (1996). These strains were originally isolated from marine mud and were described by Veldkamp (1961). Phylogenetically, these facultatively anaerobic species in the CFB complex clustered with Bacteroides (Nakagawa \& Yamasato, 1996; Paster et al., 1994). Their phylogenetic position, facultatively anaerobic properties and chemotaxonomic characteristics prompted Nakagawa \& Yamasato (1996) to transfer Cytophaga salmonicolor and Cytophaga agarovorans to a new genus, Marinilabilia, as Marinilabilia salmonicolor and Marinilabilia agarovorans. These two species have highly similar 16S rDNA and almost identical phenotypic characteristics (Nakagawa \& Yamasato, 1996; Reichenbach, 1989; Veldkamp, 1961). However, there were significant differences between these two species in their ability to decompose agar and in the $\mathrm{G}+\mathrm{C}$ contents of their chromosomal DNA : $37 \mathrm{~mol} \%$ for $M$. salmonicolor and $41 \mathrm{~mol} \%$ for M. agarovorans (Reichenbach, 1989). Nakagawa \& Yamasato (1996) concluded from these points that $M$. agarovorans and $M$. salmonicolor are closely related but distinct species.

Since a large part of the 16S rRNA sequence is important for its function, the evolutionary development of $16 \mathrm{~S}$ rDNA is very slow (Olsen \& Woese, 1993). Therefore, the resolution of a molecular phylogenetic analysis based on $16 \mathrm{~S}$ rDNA is rather low for the distinction of closely related organisms (Clayton et al., 1995; Fox et al., 1992). There are some reports indicating that $16 \mathrm{~S}$ rRNA sequence analyses were inconsistent with the results of DNA-DNA hybridization (Rainey et al., 1994; Stackebrandt \& Goebel, 1994). Yamamoto \& Harayama (1995) have recently developed a method that enables the amplification and direct sequencing of $g y r B$ genes from a variety of bacteria. The phylogenetic relationships of Acinetobacter strains deduced from the GyrB sequences were consistent with the results of DNA-DNA hybridization and of biochemical systematics (Yamamoto \& Harayama, 1996).

In this study, we performed a phylogenetic analysis of bacterial strains in the CFB complex by using their GyrB amino acid sequences, and the results prompt us to reclassify the genus Marinilabilia.

\section{METHODS}

Bacterial strains and culture conditions. The following type strains of genus Marinilabilia and related taxa were studied: M. salmonicolor IFO $15948^{\mathrm{T}}, M$. agarovorans IFO $14957^{\mathrm{T}}$, Bacteroides vulgatus IFO 14291 ${ }^{\mathrm{T}}$, Bergeyella zoohelcum ATCC $43767^{\mathrm{T}}$, Chryseobacterium indologenes IFO $14944^{\mathrm{T}}$, Chryseobacterium meningosepticum IAM 14198 ${ }^{\mathrm{T}}$, Cytophaga aurantiaca IFO $16043^{\mathrm{T}}$, Cytophaga fermentans IFO $15936^{\mathrm{T}}$, Cytophaga hutchinsonii IAM $12607^{\mathrm{T}}$, Empedobacter brevis IFO $14943^{\mathrm{T}}$, Porphyromonas asaccharolytica JCM $6326^{\mathrm{T}}$, Pedobacter heparinus IFO $12017^{\mathrm{T}}$, Sphingobacterium spiritivorum IAM $14210^{\mathrm{T}}$, Weeksella virosa ATCC $43766^{\mathrm{T}}$ and Rikenella microfusus JCM 2053 ${ }^{\mathrm{T}}$. Strictly anaerobic species were grown anaerobically with the BBL GasPack system (Becton Dickinson) in GAM broth (Nissui Pharmaceuticals) for Bacteroides vulgatus and Rikenella microfusus and in JCM medium 156 for Porphyromonas asaccharolytica. All other species were grown aerobically. The strains of genus Marinilabilia and Cytophaga fermentans were grown in marine broth 2216 (Difco Laboratories). Chryseobacterium meningosepticum, Chryseobacterium indologenes, Sphingobacterium spiritivorum, Pedobacter heparinus and Empedobacter brevis were grown in L broth $\left(10 \mathrm{~g}\right.$ tryptone $\mathrm{I}^{-1}, 5 \mathrm{~g}$ yeast extract $1^{-1}, 5 \mathrm{~g} \mathrm{NaCl}^{-1}, \mathrm{pH} \mathrm{7 \cdot 2)}$. ATCC medium 118 was used for Weeksella virosa, while ATCC medium 44 was used for Bergeyella zoohelcum and IAMB-10 medium for Cytophaga hutchinsonii and Cytophaga aurantiaca. The temperature for cultivation was $30^{\circ} \mathrm{C}$ except for Bacteroides vulgatus, Rikenella microfusus, Porphyromonas asaccharolytica, Bergeyella zoohelcum and Weeksella virosa, which were grown at $37^{\circ} \mathrm{C}$.

PCR amplification. PCR templates were prepared from each strain according to Hiraishi et al. (1995). A PCR thermal cycler MP model TP3000 (Takara) was used for the PCR amplification and sequencing reactions. PCR was performed with Ampli-Taq Gold DNA polymerase (Perkin-Elmer) in a PCR buffer (Perkin-Elmer) containing each dNTP at $200 \mu \mathrm{M}, 1.8 \mu \mathrm{M} \mathrm{MgCl}$, each primer at $1 \mu \mathrm{M}$ and $2.5 \mathrm{U}$ enzyme in a total volume of $50 \mu \mathrm{l}$. A total of 41 amplification cycles was performed. The first three cycles used the following conditions: template DNA denaturation at $95^{\circ} \mathrm{C}$ for $1 \mathrm{~min}$, primer annealing at $50^{\circ} \mathrm{C}$ for $1 \mathrm{~min}$ and primer extension at $72^{\circ} \mathrm{C}$ for $1 \mathrm{~min}$. The primer annealing temperature was elevated to $52^{\circ} \mathrm{C}$ for the next three cycles and was further elevated to $56^{\circ} \mathrm{C}$ for the subsequent 35 cycles to prevent non-specific amplification. The degenerate primers used for $\operatorname{gyr} B$ amplification were UP-21 (forward: 5'TGTAAAACGACGGCCAGTCAYGCNGGNGGNAARTTYGA-3') and 2Tr-SR1 (reverse: 5'-CCATAGCTGCGTAGCATTCATYTCNCCNARNCCYTT-3'). These primers were designed from amino acids $99-105$ and $740-745$ of the Escherichia coli DNA gyrase B subunit polypeptide $(\mathrm{GyrB})$. The amplified products were purified by gel electro- 
phoresis on $0.8 \%(\mathrm{w} / \mathrm{v})$ low-melting-point agarose (SeaPlaque GTG; FMC Bioproducts). The purified fragments were recovered from the agarose by a QIAEX II gel extraction kit (Qiagen) and used for sequencing. To determine the nucleotide sequences of both strands of each PCR product, inner degenerate primers $181 \mathrm{r}$ (reverse : $5^{\prime}$-CAGGAAACAGCTATGACCARRTGNGTNCCNCC-3'), 184f (forward: 5'-GCAACGAGATCAACACTCMNGARGGNGGNACNCA-3') and UP6r (reverse: 5'-CTGCGTTCGTATATGAGCNCCRTCNACRTCNGCRTC-3') were designed from consensus amino acid sequences of known GyrB polypeptides that correspond to amino acids 278-282, 276-281 and 498-503 of E. coli GyrB.

Sequencing. Sequencing was carried out with a Taq Dye Deoxy terminator cycle sequencing kit (ABI PRISM Cycle Sequencing FS Ready Reaction Kits; Applied Biosystems) with sequencing primers -21M13 (for UP-21-amplified fragments: 5'-TGTAAAACGACGGCCAGT-3'), SR 1 (for 2Tr-SR 1-amplified fragments: 5'-CCATAGCTGCGTAGCATTCAT-3'), M13R (for 181r-amplified fragments: 5'CAGGAAACAGCTATGACC-3'), 184sf (for 184f-amplified fragments: 5'-GCAACGAGATCAACACTC-3') and UP6sr (for UP-6-amplified fragments: 5'-CTGCGTTCGTATATGAGC-3'). The products were analysed by an ABI 373S DNA sequencer according to the manufacturer's instructions.

Phylogenetic analysis. The nucleotide sequences of $g y r B$ were translated to amino acid sequences and these GyrB sequences were aligned by using CLUSTAL w software (Thompson et al., 1994). Any gaps were excluded manually from the aligned sequences. An evolutionary tree was reconstructed with MORPHY version $2.3 \mathrm{~b} 3$ software by using the maximum-likelihood method (Kishino et al., 1990).

Preparation of chromosomal DNA. DNA for $\mathrm{G}+\mathrm{C}$ content determination and DNA-DNA hybridization was obtained by the method described by Marmur (1961) and by Saito \& Miura (1963) with the modifications described previously (Nakagawa et al., 1996). Extracted chromosomal DNA was purified by using hydroxyapatite to exclude polysaccharides.

DNA base composition. DNA base composition of the Marinilabilia strains was determined by the method of Mesbah et al. (1989), using HPLC with an Asahipak GS320 column $(7.6 \times 250 \mathrm{~mm}$; Showa Denko) and $50 \mathrm{mM}$ $\mathrm{NaH}_{2} \mathrm{PO}_{4}(\mathrm{pH} 5.0$ ) as the mobile phase.

DNA-DNA hybridization. The genetic relatedness between the Marinilabilia strains was determined by using fluorometric DNA-DNA hybridization in microdilution wells according to the method described by Ezaki et al. (1989). The hybridization reaction was performed at $45^{\circ} \mathrm{C}$ in $2 \times$ $\mathrm{SSC}(1 \times \mathrm{SSC}$ is $0.15 \mathrm{M} \mathrm{NaCl}, 15 \mathrm{mM}$ sodium citrate, $\mathrm{pH}$ $7 \cdot 0)$ supplemented with $50 \%(\mathrm{v} / \mathrm{v})$ formamide.

\section{RESULTS AND DISCUSSION}

\section{gyrB sequences of strains of the CFB complex}

Approximately $1.4 \mathrm{kbp}$-long DNA fragments were amplified by PCR from all the tested strains by using the primers described in Methods. The nucleotide sequences of the amplified fragments were determined. These sequences each had about $55 \%$ identity to the gyr $B$ sequence of $E$. coli and exhibited 62.6-100\% identity to each other. The amino acid sequences deduced from the nucleotide sequences had the signature sequences of type II DNA topoisomerases, i.e. EGDSA and PL(R/K)G (Watt \& Hickson, 1994). While the $\operatorname{gyr} B$ sequences of the two Marinilabilia species were identical, they were not closely related to those of the other species (65.0-78.9\% identity in their amino acid sequences).

\section{Phylogenetic structure of the CFB complex based on GyrB amino acid sequences}

The phylogenetic tree (Fig. 1) for the strains of Marinilabilia and related bacteria was derived from their GyrB amino acid sequences by using the maximum-likelihood method. Chryseobacterium meningosepticum, Chryseobacterium indologenes, Bergeyella zoohelcum, Weeksella virosa and Empedobacter brevis, which each possess menaquinone- 6 as the major molecule of the quinone system (Nakagawa \& Yamasato, 1996), formed one cluster. The strains of genus Marinilabilia were clustered with the other anaerobic species, Bacteroides vulgatus, Porphyromonas asaccharolytica, Cytophaga fermentans and Rikenella microfusus. The sphingolipid-containing aerobic species (Takeuchi \& Yokoto, 1992; Yano et al., 1982) Pedobacter heparinus IFO $12017^{\mathrm{T}}$ and Sphingobacterium spiritivorum IAM $14210^{\mathrm{T}}$ formed a cluster that branched earlier than the clusters just mentioned. Cytophaga hutchinsonii, the type species of the genus Cytophaga, and Cytophaga aurantiaca formed a deeper cluster that fell outside the sphingolipid-containing group.

Among the anaerobic species, the facultatively anaerobic species Cytophaga fermentans was located with the same lineage as the genus Marinilabilia, and their GyrB amino acid sequences were similar to each other (78.9\% identity). A bootstrap analysis indicated that the anaerobic cluster (Marinilabilia strains, Cytophaga fermentans, Rikenella microfusus, Porphyromonas asaccharolytica and Bacteroides vulgatus) had a confidence value of $96 \%$. The lineage of the facultatively anaerobic species (genera Marinilabilia and Cytophaga fermentans) also had a high confidence value $(99 \%)$.

We also reconstructed a phylogenetic tree on the basis of the gyr $B$ nucleotide sequences. The constructed tree topology was almost identical to that based on GyrB amino acids sequences with some exceptions. A match between the $g y r B$ - and GyrB-based trees was observed when only the first two bases of each codon were used for the analysis (data not shown).

\section{Comparison with other phylogenetic methods}

Analyses by some researchers (Nakagawa \& Yamasato, 1996; Paster et al., 1994) of the phylogenetic relationships among the genus Marinilabilia and related bacteria have been based on $16 \mathrm{~S}$ rDNA, and it was suggested that genus Marinilabilia falls within a bacteroides subcluster of the CFB phylum. Paster et al. 


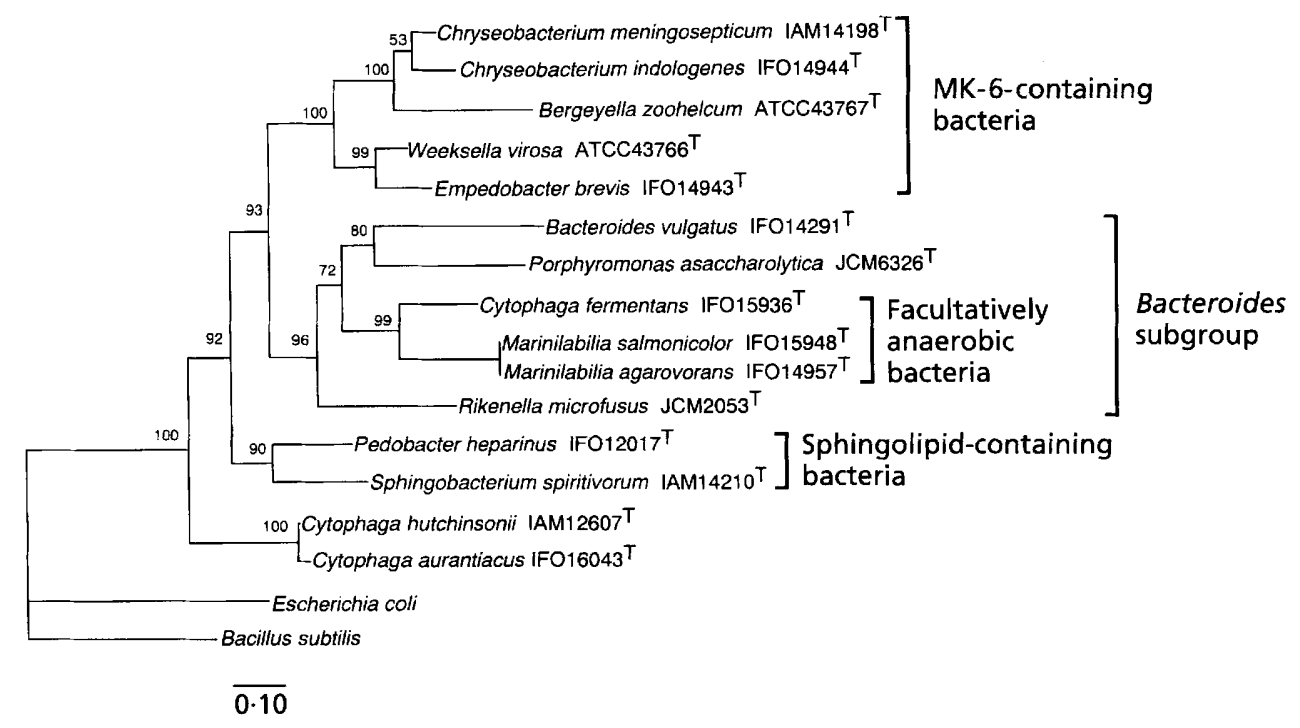

Fig. 1. Phylogenetic tree for genus Marinilabilia and related bacteria deduced from GyrB amino acid sequences by the maximum-likelihood method and using the JTT-F model (Jones et al., 1992) for the transition matrix. The numbers shown next to the nodes indicate the percentage bootstrap probability by resampling with the estimated-likelihood method (Kishino et al., 1990). Bar, 0.1 substitutions per mean amino acid residue.

(1994) have suggested that the cluster of M. salmonicolor and Cytophaga fermentans and that of Rikenella microfusus and Bacteroides putredinis were connected with other bacteroides and their relatives at a deeper branch. However, the bootstrap confidence level was only $76 \%$, so it is not clear whether these species are included in the bacteroides subcluster or form another sub-group of the CFB phylum. Nakagawa \& Yamasato (1996) performed a phylogenetic analysis of the CFB phylum by using $16 \mathrm{~S}$ rDNA sequences. They showed a high level of $16 \mathrm{~S}$ rDNA sequence identity $(98.9 \%)$ for the two Marinilabilia species. They also reported that genus Marinilabilia clustered with Bacteroides splanchnicus rather than with Cytophaga fermentans. However, the bootstrap confidence level for this clustering was not very high.

In contrast to the previous observations, the bootstrap confidence level of the anaerobic cluster in the phylogenetic tree based on the GyrB amino acid sequences was quite high $(96 \%)$. This high confidence level prompts us to conclude that genus Marinilabilia is included in the bacteroides subcluster of the CFB phylum.

\section{DNA-DNA hybridization of genus Marinilabilia}

The close relationship between $M$. salmonicolor and $M$. agarovorans has been indicated from phylogenetic analyses of 16S rDNA sequences (Nakagawa \& Yamasato, 1996) and GyrB sequences (this study). To confirm this close relationship, a DNA-DNA hybridization experiment was performed. The DNA relatedness between these two strains in genus Marinilabilia is consistent with the results of the GyrB sequence analysis (Table 1). The DNA relatedness between $M$. salmonicolor IFO $15948^{\mathrm{T}}$ and $M$. agarovorans IFO $14957^{\mathrm{T}}$ was over $70 \%$. However, Cytophaga fermentans IFO $15936^{\mathrm{T}}$ showed only a low level of DNA relatedness to each of the Marinilabilia species.

\section{Re-evaluation of the species of genus Marinilabilia}

The close relationship between $M$. salmonicolor and $M$. agarovorans has been suggested previously on the basis of similarities in the biochemical and chemotaxonomical characteristics of these organisms (Hamana et al., 1995; Nakagawa \& Yamasato, 1996; Reichenbach, 1989). The obvious differences were the ability to decompose agar and the $\mathrm{G}+\mathrm{C}$ content of DNA. Reichenbach (1989) has mentioned that there was a small percentage difference in the $\mathrm{G}+\mathrm{C}$ content between $M$. agarovorans and $M$. salmonicolor. The $\mathrm{G}+\mathrm{C}$ contents of $M$. agarovorans and $M$. salmonicolor were reported as 41 and $37 \%$. We determined the $\mathrm{G}+\mathrm{C}$ content of DNA of these bacteria by an HPLC analysis of the deoxynucleosides that were generated by $\mathrm{P} 1$ nuclease digestion and bacterial alkaline phosphatase dephosphorylation of DNA. Our results show that the $\mathrm{G}+\mathrm{C}$ contents of these two bacteria were almost the same. The $\mathrm{G}+\mathrm{C}$ contents of strains IFO $14957^{\mathrm{T}}\left(M\right.$. agarovorans) and IFO $15948^{\mathrm{T}}(M$. salmonicolor) were $41 \cdot 2$ and $41.5 \%$. This information enables us to conclude that $M$. salmonicolor IFO $15948^{\mathrm{T}}$ and $M$. agarovorans IFO $14957^{\mathrm{T}}$ belong to a single species. Since $M$. salmonicolor was described first, as Cytophaga salmonicolor, $M$. salmonicolor is a senior subjective synonym of $M$. agarovorans. Strain IFO $14957^{\mathrm{T}}$ should be reclassified as $M$. salmonicolor. However, the agar-degrading ability of strain IFO $14957^{\mathrm{T}}$ is a prominent biochemical characteristic; 
Table 1. DNA base composition and DNA-DNA hybridization results for Marinilabilia strains

\begin{tabular}{|c|c|c|c|}
\hline \multirow[t]{2}{*}{ Strain } & \multirow{2}{*}{$\begin{array}{c}G+C \text { content } \\
(\mathrm{mol} \%)\end{array}$} & \multicolumn{2}{|c|}{ Reassociation (\%) with DNA from: } \\
\hline & & IFO $14957^{\mathrm{T}}$ & IFO $15948^{\mathrm{T}}$ \\
\hline Marinilabilia agarovorans IFO $14957^{\mathrm{T}}$ & $41 \cdot 2$ & 100 & 78 \\
\hline Marinilabilia salmonicolor IFO $15948^{\mathrm{T}}$ & $41 \cdot 5$ & 88 & 100 \\
\hline Cytophaga fermentans IFO $15936^{\mathrm{T}}$ & ND & 5 & 5 \\
\hline
\end{tabular}

ND, Not determined.

therefore this strain should be recognized as biovar agarovorans of $M$. salmonicolor.

\section{Emended description of Marinilabilia salmonicolor (Veldkamp 1961) Nakagawa and Yamasato 1996}

Marinilabilia salmonicolor (sal.mo.ni'co.lor. L. masc. gen. n. salmo of salmon; L. masc. n. color colour; M. L. adj. salmonicolor salmon-coloured).

Cells are slender, flexible, cylindrical rods with rounded or slightly tapering ends, $0 \cdot 3-0 \cdot 5 \times 2-50 \mu \mathrm{m}$ (usually around $10-20 \mu \mathrm{m}$ in length). Resting stages are not observed. Motile by gliding. Gram-negative. Colour of cell mass is salmon to pink. Chemoorganotroph. Facultative anaerobe. Good growth is obtained in a normal aerobic atmosphere. Marine organism that requires elevated salt concentrations. Peptones, Casamino acids, yeast extracts, ammonium and nitrate are suitable nitrogen sources. Arabinose, xylose, glucose, galactose, mannose, fructose, sucrose, lactose, maltose, cellobiose, trehalose, raffinose, inulin and starch are fermented. Gelatin is slowly liquefied. Catalase is produced. The optimum temperature is $28-37^{\circ} \mathrm{C}$. The optimum $\mathrm{pH}$ is around 7 . The quinone is MK-7. The major polyamine is spermidine. The $\mathrm{G}+\mathrm{C}$ content of the DNA is $41 \cdot 2-41 \cdot 5 \mathrm{~mol} \%$. Type strain is IFO $15948^{\mathrm{T}}$. The other strain, IFO 14957 , which can degrade agar, is a reference strain of biovar agarovorans.

\section{Concluding remarks}

The description of genus Marinilabilia should also be emended. The $\mathrm{G}+\mathrm{C}$ content of this genus is $41 \cdot 2-41 \cdot 5$ $\mathrm{mol} \%$ and there is only one species included. Other characteristics of this taxon are the same as those described for the genus and those described by Nakagawa \& Yamasato (1996).

The another facultatively anaerobic species, Cytophaga fermentans, is clearly misclassified in the genus Cytophaga. This species is distantly related to other Cytophaga species on the basis of 16S rDNA sequence comparisons (Nakagawa \& Yamasato, 1993, 1996; Paster et al., 1994) and GyrB sequence comparisons. Cytophaga fermentans is a neighbour of genus Marinilabilia. However, there is not a close identity $(78.9 \%)$ between their GyrB sequences, and DNA relatedness between Cytophaga fermentans and Marinilabilia strains was very low (Table 1). Therefore, a new genus should be created to accommodate Cytophaga fermentans.

\section{ACKNOWLEDGEMENTS}

We are grateful to Kazuhide Yamasato for encouragement and to Nakako Hayashi and Yoshio Sasaki for technical assistance. This work was supported by a grant-in-aid from the Industrial Science and Technology Frontier Program of the New Energy and Industrial Technology Development Organization.

\section{REFERENCES}

Bachmann, B. J. (1955). Studies on Cytophaga fermentans, n.sp., a facultatively anaerobic lower myxobacterium. J Gen Microbiol 13, 541-551.

Bernardet, J.-F., Segers, P., Vancanneyt, M., Berthe, F., Kersters, K. \& Vandamme, P. (1996). Cutting a Gordian knot: emended classification and description of the genus Flavobacterium, emended description of the family Flavobacteriaceae, and proposal of Flavobacterium hydatis nom. nov. (basonym, Cytophaga aquatilis Strohl and Tait 1978). Int J Syst Bacteriol 46, 128-148.

Callies, E. \& Mannheim, W. (1978). Classification of the Flavobacterium-Cytophaga complex on the basis of respiratory quinones and fumarate respiration. Int $J$ Syst Bacteriol 28, 14-19.

Christensen, P. J. (1977). The history, biology, and taxonomy of the Cytophaga group. Can J Microbiol 23, 1599-1653.

Clayton, R. A., Sutton, G., Hinkle, P. S., Jr, Bult, C. \& Fields, C. (1995). Interspecific variation in small-subunit $r$ RNA sequences in GenBank: why single sequences may not adequately represent prokaryotic taxa. Int J Syst Bacteriol 45, 595-599.

Ezaki, T., Hashimoto, Y. \& Yabuuchi, E. (1989). Fluorometric deoxyribonucleic acid-deoxyribonucleic acid hybridization in microdilution wells as an alternative to membrane filter hybridization in which radioisotopes are used to determine genetic relatedness among bacterial strains. Int $J$ Syst Bacteriol 39, 224-229.

Fox, G. E., Wisotzkey, J. D. \& Jurtshuk, P., Jr (1992). How close is close: 16S rRNA sequence identity may not be sufficient to guarantee species identity. Int $J$ Syst Bacteriol 42, 166-170.

Gherna, R. \& Woese, C. R. (1992). A partial phylogenetic analysis of the Flavobacterium-Bacteroides phylum: basis for taxonomic restructuring. Syst Appl Microbiol 15, 513-521. 
Hamana, K., Nakagawa, Y. \& Yamasato, K. (1995). Chemotaxonomic significance of polyamine distribution patterns in the Flavobacterium-Cytophaga complex and the related genera. Microbios 81, 135-145.

Hayes, P. R. (1977). A taxonomic study of flavobacteria and related gram negative yellow pigmented rods. $J$ Appl Bacteriol 43, 345-367.

Hiraishi, A., Furuhata, K., Matsumoto, A., Koike, K. A., Fukuyama, M. \& Tabuchi, K. (1995). Phenotypic and genetic diversity of chlorine-resistant Methylobacterium strains isolated from various environments. Appl Environ Microbiol 61, 2099-2107.

Jones, D. T., Taylor, W. R. \& Thornton, J. M. (1992). The rapid generation of mutation data matrices from protein sequences. Comput Appl Biosci 8, 275-282.

Kishino, H., Miyata, T. \& Hasegawa, M. (1990). Maximum likelihood inference of protein phylogeny and the origin of chloroplasts. J Mol Evol 30, 151-160.

Marmur, J. (1961). A procedure for the isolation of deoxyribonucleic acid from microorganisms. $J \mathrm{Mol}$ Biol 3, 208-218.

Mesbah, M., Premachandran, U. \& Whitman, W. B. (1989). Precise measurement of the $\mathrm{G}+\mathrm{C}$ content of deoxyribonucleic acid by high-performance liquid chromatography. Int $J$ Syst Bacteriol 39, 159-167.

Nakagawa, Y. \& Yamasato, K. (1993). Phylogenetic diversity of the genus Cytophaga revealed by 16S rRNA sequencing and menaquinone analysis. $J$ Gen Microbiol 139, 1155-1161.

Nakagawa, Y. \& Yamasato, K. (1996). Emendation of the genus Cytophaga and transfer of Cytophaga agarovorans and Cytophaga salmonicolor to Marinilabilia gen. nov.: phylogenetic analysis of the Flavobacterium-Cytophaga complex. Int $J$ Syst Bacteriol 46, 599-603.

Nakagawa, Y., Hamana, K., Sakane, T. \& Yamasato, K. (1997). Reclassification of Cytophaga aprica (Lewin 1969) Reichenbach 1989 in Flammeovirga gen. nov. as Flammeovirga aprica comb. nov. and of Cytophaga diffluens (ex Stanier 1940; emend. Lewin 1969) Reichenbach 1989 in Persicobacter gen. nov. as Persicobacter diffluens comb. nov. Int J Syst Bacteriol 47, 220-223.

Nakagawa, Y., Sakane, T. \& Yokota, A. (1996). Transfer of 'Pseudomonas riboflavina' (Foster 1944), a gram-negative, motile rod with long-chain 3-hydroxy fatty acids, to Devosia riboflavina gen. nov., sp. nov., nom. rev. Int J Syst Bacteriol 46, 16-22.

Olsen, G. J. \& Woese, C. R. (1993). Ribosomal RNA : a key to phylogeny. FASEB J 7, 113-123.

Oyaizu, H. \& Komagata, K. (1981). Chemotaxonomic and phenotypic characterization of the strains of species in the Flavobacterium-Cytophaga complex. J Gen Appl Microbiol 25, 57-107.

Palleroni, N. J., Kunisawa, R., Contopoulou, R. \& Doudoroff, M. (1973). Nucleic acid homologies in the genus Pseudomonas. Int J Syst Bacteriol 23, 333-339.

Paster, B., Ludwig, J. W., Weisburg, W. G., Stackebrandt, E., Hespell, R. B., Hahn, C. M., Reichenbach, H., Stetter, K. O. \& Woese, C. R. (1985). A phylogenetic grouping of the bacteroides, cytophagas, and certain flavobacteria. Syst Appl Microbiol 6, $34-42$.

Paster, B. J., Dewhirst, F. E., Olsen, I. \& Fraser, G. J. (1994). Phylogeny of Bacteroides, Prevotella, and Porphyromonas spp. and related bacteria. $J$ Bacteriol 176, 725-732.

Rainey, F. A., Lang, E. \& Stackebrandt, E. (1994). The phylogenetic structure of the genus Acinetobacter. FEMS Microbiol Lett 124, 349-353.
Reichenbach, H. (1989). Genus I. Cytophaga. In Bergey's Manual of Systematic Bacteriology, vol. 3, pp. 2015-2050. Edited by J. T. Staley, M. P. Bryant, N. Pfennig \& J. G. Holt. Baltimore: Williams \& Wilkins.

Saito, H. \& Miura, K. (1963). Preparation of transforming deoxyribonucleic acid by phenol treatment. Biochim Biophys Acta 72, 916-929.

Segers, P., Mannheim, W., Vancanneyt, M., De Brandt, K., Hinz, K.-H., Kersters, K. \& Vandamme, P. (1993). Riemerella anatipestifer gen. nov., comb. nov., the causative agent of septicemia anserum exsudativa, and its phylogenetic affiliation within the Flavobacterium-Cytophaga rRNA homology group. Int J Syst Bacteriol 43, 768-776.

Shah, H. N. \& Collins, M. D. (1988). Proposal for reclassification of Bacteroides asaccharolyticus, Bacteroides gingivalis, and Bacteroides endodontalis in a new genus, Porphyromonas. Int $J$ Syst Bacteriol 38, 128-131.

Shewan, J. M. \& McMeekin, T. A. (1983). Taxonomy (and ecology) of Flavobacterium and related genera. Annu Rev Microbiol 37, 233-252.

Stackebrandt, E. \& Goebel, B. M. (1994). Taxonomic note: a place for DNA-DNA reassociation and 16S rRNA sequence analysis in the present species definition in bacteriology. Int $J$ Syst Bacteriol 44, 846-849.

Stanier, R. Y. (1940). Studies on the cytophagas. J Bacteriol $\mathbf{4 0 ,}$ 619-635.

Stanier, R. Y. (1941). Studies on marine agar-digesting bacteria. $J$ Bacteriol 41, 527-559.

Stanier, R. Y. (1942). The Cytophaga group: a contribution to the biology of myxobacteria. Bacteriol Rev 6, 143-196.

Steyn, P. L., Segers, P., Vancanneyt, M., Sandra, P., Kersters, K. \& Joubert, J. J. (1998). Classification of heparinolytic bacteria into a new genus, Pedobacter, comprising four species: Pedobacter heparinus comb. nov., Pedobacter piscium comb. nov., Pedobacter africanus sp. nov. and Pedobacter saltans sp. nov. Proposal of the family Sphingobacteriaceae fam. nov. Int $J$ Syst Bacteriol 48, 165-177.

Takeuchi, M. \& Yokoto, A. (1992). Proposals of Sphingobacterium faecium sp. nov., Sphingobacterium piscium sp. nov., Sphingobacterium heparinum comb. nov., Sphingobacterium thalpophilum comb. nov. and two genospecies of the genus Sphingobacterium, and synonymy of Flavobacterium yabuuchiae and Sphingobacterium spiritivorum. J Gen Appl Microbiol 38, 465-482.

Thompson, J. D., Higgins, D. G. \& Gibson, T. J. (1994). CLUSTAL W: improving the sensitivity of progressive multiple sequence alignment through sequence weighting, position-specific gap penalties and weight matrix choice. Nucleic Acids Res 22, 4673-4680.

Veldkamp، H. (1961). A study of two marine agar-decomposing, facultatively anaerobic myxobacteria. J Gen Microbiol 26, 331-342.

Watt, P. M. \& Hickson, I. D. (1994). Structure and function of type II DNA topoisomerases. Biochem $J$ 303, 681-695.

Weisburg, W. G., Oyaizu, Y., Oyaizu, H. \& Woese, C. R. (1985). Natural relationship between bacteroides and flavobacteria. $J$ Bacteriol 164, 230-236.

Winogradsky, S. (1929). Etudes sur la microbiologie du sol. Sur la degradation de la cellulose dans le sol. Ann'Inst Pasteur 43, 549-633.

Woese, C. R. (1987). Bacterial evolution. Microbiol Rev 51, 221-271. 
Woese, C. R., Stackebrandt, E., Macke, T. J. \& Fox, G. E. (1985). A phylogenetic definition of the major eubacterial taxa. Syst Appl Microbiol 6, 143-151.

Yamamoto, S. \& Harayama, S. (1995). PCR amplification and direct sequencing of $g y r B$ genes with universal primers and their application to the detection and taxonomic analysis of Pseudomonas putida strains. Appl Environ Microbiol 61, 1104-1109.
Yamamoto, S. \& Harayama, S. (1996). Phylogenetic analysis of Acinetobacter strains based on the nucleotide sequences of gyr $B$ genes and on the amino acid sequences of their products. Int $J$ Syst Bacteriol 46, 506-511.

Yano, I., Tomiyasu, I. \& Yabuuchi, E. (1982). Long chain base composition of strains of three species of Sphingobacterium gen. nov. FEMS Microbiol Lett 15, 303-307. 